\title{
The physico-chemical properties of cassava starch in relation to the texture of the cooked root
}

\author{
O. SAFO-KANTANKA\& RITAACQUISTUCCI \\ (O.S.: Department of Crop Science, University of Science and Technology, Kumasi, Ghana; R.A.: \\ National Nutrition Institute, Rome, Italy)
}

\section{ABSTRACT}

The proximate composition, pasting cycle, swelling power and solubility of six cassava varieties harvested at 13 months and nine varieties harvested at 6 months were determined and compared with the mealiness of the cooked root and the elasticity and smoothness of the pounded paste. Differences were established between the varieties in their cooking quality especially in the mealiness rankings. The age at harvest affected the cooking quality of some varieties. The varieties also differed in their proximate composition and this was also affected by the age at harvest. None of the components on its own could explain all the differences in cooking quality between the varieties. The pasting cycle of the starch showed large variations between varieties harvested at the same age, between the two harvesting ages and between the starch and flour of the same variety. These differences were explained on the basis of the variation in the rate of swelling of the starch granules and the fragility of the swollen granules. However, it was not possible to establish any direct relationship between the cooking quality parameters and specific points on the amylograph. The varieties again differed in swelling power and solubility of starch determined at $85^{\circ} \mathrm{C}$, which confirmed the results of the amylograph studies that the varieties differed in the strength of the binding forces between the granules. The swelling power and solubility of starch of three varieties with contrasting cooking qualities determined over $60.95^{\circ} \mathrm{C}$ showed that a variety with good cooking quality is one in which the starch granules neither swell too rapidly nor too slowly on heating.

Original scientific paper. Received 10 Apr 95; revised 14 Mar 96.

\section{Introduction}

Cassava (Manihot esculenta, Crantz) is an important staple in most parts of Africa and other tropical areas. In Ghana, it is used in many food prepara-

\begin{abstract}
RÉSUMÉ
Safo-Kantanka, O. \& AcQuistucci, Ruta: les propriétés physico-chemiques de fécule de manioc par rapport à la texture de la racine cuite. La constitution immédiate, le cycle de la raclée, le pouvoir de gonflement et la solubilité de six variétés de manioc récoltées à 13 mois et de neuf varietés récoltées à 6 mois, étaient déterminées et comparées avec l'aspect farineux de la racine cuite ainsi que l'élasticité et l' aspect lisse de la pâte pilonnée. Des différences étaient établies entre les variétés dans leurs qualités de cuisson surtout dans les classsments de leur nature farineuse. L' âge pendant la récolte affectait la qualité de cuisson de certaines variétés. Les variétès se sont distinguées dans̀ leur composition immédiate et ceci était également influencé par l' âge pendant la récolte. Aucun des composants pourrait en lui même expliquer toutes les différences en qualité de cuisson entre les variétés. Le cycle de la raclée de fécule montrait des grandes différences entre les variétés récoltées au même âge, untro les deux âges de récolte et entre la fécule et la farine de la même variétés. Ces différences étaient expliquées en fonction de la proportion de variation de gonflement de granulés de fécule et la fragilité des granulés gonflés. Cependant, il n'etait pas possible d'etablir aucum rapport direct entre les paramètres de la qualité de cuisson et des points spécifiques sur l' amylographe. Encore, les variété se sont distinguées en pouvoir de gonflement et en solubilité de fécule déterminée à $85^{\circ} \mathrm{C}$, qui confirmait les résultats des études anylographes que les variétés se distinguaient à l' égard de la puissance des forces de cohésion entrte les granulés. Le pouvoir de gonflement et la solubilité de fécule de trois variétés ayant contraste en qualitiés de cuisson déterminées par-dessus de 60-95 $\mathrm{C}$ montraient qu' une variété avec une bonne qualité de cuisson est celle sur laquelle les granulés de fécule ne se gonflent ni trcp rapidement ni trop lentement au chaufage.
\end{abstract}

tions including ampesi, fufu, kokonte, gari, yakoyake and agbeli-krakro. The preparation of the last three products involves some kind of fermentation and so the cooking quality of the 
fresh root is not important. Ampesi is the boiled or roasted root eaten with a vegetable sauce, and it is important that the cooked root be mealy. Fufu which is the boiled root pounded into a paste and eaten with soup must be elastic and free of lumps (referred to as smoothness) in order to be acceptable. These fufu-eating qualities also apply to kokonte, which is the flour cooked and stirred into a paste and eaten with soup. The changes in elasticity that take place in the fufu and kokonte if consumption is delayed are also important to the consumer.

In spite of these many uses, there is little information on which the plant breeder can depend to select different genotypes that are suited for particular uses. There is a tendency, therefore, for farmers to reject a disease-resistant and high-yielding variety, if it is found to be unsuitable for their particular food preparations.

According to Howard (1974), the Potato Quality Research Working Party of the European Association for Potato Research distinguishes between four types of potato based on what they are used for. There are types used for salad and boiling; multipurpose types used for chips, mashing, baking and salad and boiling; multipurpose types used for chips, mashing, baking and salad; mealy types used for mashing and baking and very mealy types used for mashing. These are grouped into categories $\mathrm{A}, \mathrm{B}, \mathrm{C}$ and $\mathrm{D}$ respectively.

The classification is based on the texture, colour, discolouration and flavour of the cooked tuber and of these factors, texture is the most important. Linehan \& Huges (1969) concluded from their review that variations in the texture of the cooked potato can be only partly explained by variations in the starch content of the tuber. Bettelheim \& Sterling (1955) found no relationship between the texture of the cooked potato and amylose content.

The ability of the starch granule to sell and yield a viscous paste is considered by Rasper (1982) to be among the most important practical properties of starch, since it affects its rheological properties. Mazurs, Schoch \& Kite (1957) were the first to interpret the various points on the amylograph in terms of the practical rheological properties of the starch paste. Another important characteristic of the starch granule which also affects its rheological properties is the nature and strength of the associative forces between the granules. The differences in swelling and solubilization patterns of various starches can, therefore, also be explained on the basis of the differences in the character and strength of the micellar network within the granule (Rasper, 1969).

In cassava, very little information is available on the factors that influence the cooking quality and other uses of the root. The objective of this work, therefore, was to study the proximate composition, pasting cycle, swelling power and solubility of the starches of a number of cassava varieties and to find out the relationships that exist between these starch properties and the sensory evaluation of their cookmg quality. Such knowledge will assist the plant breeder in developing selection techniques, and in breeding cassava varieties suited for specific uses.

\section{Materials and methods}

Segregates of cassava varieties developed at the International Institute of Tropical Agriculture (IITA) in Nigeria and some local Ghanaian varieties were used in these experiments. The first group (Set A) consisted of six varieties and was harvested at 13 months while the second group (Set B) was made up of nine varieties harvested at 6 months. The cooking quality parameters considered at harvest were the mealiness of the cooked root and the elasticity and smoothness of the pounded paste. The method of Safo-Kantanka \& Owusu-Nipah (1992) was followed in determining the cooking quality. This involved the use of a six-member "trained" panel made up of regular cassava consumers, to score the cooked root for mealiness and the pounded paste for its elasticity and presence or absence of lumps (smoothness). The rest of the harvested root was peeled and cut into thin slices and dried at $60^{\circ} \mathrm{C}$ in the oven for $48 \mathrm{~h}$. The bulk of the dried chips was taken to the National Nutrition Institute in Rome, Italy, where the rest of the 
analysis was carried out. The dry chips were milled into flour using a pin mill (Buhler Niag-NLI202, Milan, Italy). Starch wasextracted from the flour by washing liberally with distilled water. The starch was dried at room temperature, pulverized and stored for subsequent use. The flour used in the analyses was finely milled in a cyclotec mill (Cyclotec 1033 Tecator, Hoganas, Sweden).

\section{Proximate composition}

The AOAC $(1984,1990)$ methods of analysis were used in determining the fat, protein, ash and fibre contents of the samples. The starch content was determined following the acid hydrolysis method as described by Rickard \& Behn ( 1987) and amylose content was determined by the iodine colorimetric method as described by McCready \& Hassid (1943). It was not possible to carry out the fat and protein analyses for varieties in Set B. In all cases, at least duplicate samples per variety were analyzed.

\section{Hot-paste viscosity}

The standard Brabender amylograph procedure was followed (Brabender Ohg Duisburg, 1989). A starch suspension $\left(70 \mathrm{~g} t^{-1}, 500 \mathrm{ml}\right)$ was placed in the cup of the standard Brabender (Duisburg, Germany) amylograph and heated until a base temperature of $50^{\circ} \mathrm{C}$ was attained. Heating continued from $50^{\circ} \mathrm{C}$ to $95^{\circ} \mathrm{C}$ and held for one hour then cooled to $50^{\circ} \mathrm{C}$ and held for an hour. The heating rate was 1.5 ${ }^{\circ} \mathrm{C}$ min $^{-1}$ and the bowl speed was $75 \mathrm{rev} \mathrm{min}^{-1}$ using a $700 \mathrm{~cm} \mathrm{~g}^{-1}$ measuring cartridge. The flour was run at two concentrations of 70 and $100 \mathrm{~g} l^{-1}$.

\section{Swelling power and solubility}

The method of Schoch (1964) was adapted using $1 \mathrm{~g} \mathrm{starch}(\mathrm{db})$ suspended in $50 \mathrm{ml}$ of distilled water in $75 \mathrm{ml}$ centrifuge bottles and heating at $85^{\circ} \mathrm{C}$ in a water bath for $30 \mathrm{~min}$ while stirring slowly. The solubility and swelling power of the starches of the three varieties Ankra, 91934 and 30474 which showed distinct differences in their amylograms were determined over the temperature range of $60-95^{\circ} \mathrm{C}$ at $5^{\circ} \mathrm{C}$ intervals. All measurements were made in triplicate.

\section{Results and discussion}

Analysis of Variance (ANOVA) and correlation analysis were carried out on the data to establish differences between the varieties and relationships between the sensory evaluation and the physicochemical properties of the starch and flour.

\section{Cooking quality}

TABLE 1

Cooking Quality Ranking of Cassava Varieties Harvested at 13 Months (Set A)

\begin{tabular}{lccc}
\hline Variety & $\begin{array}{c}\text { Mealiness } \\
\text { of cooked } \\
\text { tuber }\end{array}$ & $\begin{array}{c}\text { Elasticity } \\
\text { of pounded } \\
\text { paste }\end{array}$ & $\begin{array}{c}\text { Smoothness } \\
\text { of pounded } \\
\text { paste }\end{array}$ \\
\hline Ankra* & 4.0 & 4.0 & 4.0 \\
91934 & 1.5 & 3.0 & 2.5 \\
$\begin{array}{l}\text { Isunikaniyan-W } \\
\text { (ISU-W) }\end{array}$ & 3.1 & 4.0 & 4.0 \\
3000 ) -W & 3.5 & 4.0 & 3.5 \\
30474 & 2.1 & 4.0 & 2.9 \\
60142 & 2.9 & 4.0 & 3.6 \\
\hline
\end{tabular}

Variety Harvested at 6 Mtonths (Set B)

\begin{tabular}{llll}
\hline Ankra* & 4.0 & 4.0 & 4.0 \\
Akosua- Tumtum & 3.2 & 4.0 & 3.5 \\
Atra* & 3.0 & 3.8 & 4.0 \\
60142 & 2.8 & 3.2 & 2.7 \\
JSU-W & 2.3 & 3.8 & 2.7 \\
$518-\mathrm{DB}$ & 2.7 & 3.2 & 3.0 \\
30001-W & 2.7 & 3.7 & 2.5 \\
ISU-DB & 3.0 & 3.2 & 2.2 \\
1425-DB & 2.0 & 3.2 & 2.2 \\
\hline
\end{tabular}

+ The rankings are the mean score of 6 panelists.

* Local varieties.

\section{Description of ranking}

\begin{tabular}{|c|c|c|c|}
\hline Scale & Mealiness & Elasticity & Smoothness \\
\hline 1 & Poor & Not elastic & $\begin{array}{l}\text { Not smooth or } \\
\text { lumpy }\end{array}$ \\
\hline 2 & Fair & Fair & Fair \\
\hline 3 & Good & Good & Good \\
\hline 4 & Very Good & Very Good & Very Good \\
\hline
\end{tabular}


There was a great deal of variation in the cooking quality rankings of the varieties (Table 1). The local varieties were generally better cooking types than the IITA segregants. There was greater variation in the mealiness of the cooked root and the smoothness of the pounded paste than in the elasticity of the paste. This shows that even though a root may be non-mealy when cooked, an elastic paste may be produced when pounded, but the paste may not necessarily be smooth. The varieties harvested at 6 months received lower cooking quality rankings than those harvested at 13 months. The only exception was Ankra in which the rankings in both maturity groups were the same. This shows that the age at harvest may affect the cooking quality of some varieties.

Proximate composition of root and starch

TABLE 2

Proximate Composition of the Root and Starch of Root Cassava Harvested at 13 Months

\begin{tabular}{lccccc}
\hline Varieties & $\begin{array}{c}\text { Starch } \\
\left(g k g^{-1}\right)\end{array}$ & $\begin{array}{c}\text { Fat } \\
\left(g k g^{-1}\right)\end{array}$ & $\begin{array}{c}\text { Protein } \\
\left(g^{\prime} g^{-1}\right)\end{array}$ & $\begin{array}{c}\text { Ash } \\
\left(g^{-1}\right)\end{array}$ & $\begin{array}{c}\text { Fibre } \\
\left(g^{-1}\right)\end{array}$ \\
\hline Ankra & 713 & 16.6 & 9.9 & 17.0 & 56.8 \\
91934 & 692 & 15.8 & 9.3 & 12.7 & 61.2 \\
ISU-W & 699 & 18.7 & 7.4 & 16.0 & 54.4 \\
$30001-W$ & 706 & 22.3 & 7.9 & 17.2 & 60.0 \\
30474 & 689 & 17.8 & 8.0 & 11.9 & 83.7 \\
60142 & 702 & 21.5 & 6.1 & 12.1 & 74.2 \\
LSD at 5\% & 22.2 & 1.3 & 3.7 & 0.5 & 3.6 \\
LSD at 1\% & 29.6 & 1.7 & 4.9 & 0.7 & 4.8 \\
CV per cent & 1.57 & 4.23 & 22.7 & 1.85 & 2.76 \\
\hline
\end{tabular}

Starch

\begin{tabular}{lcrrr}
\hline Varieties & $\begin{array}{c}\text { Amylose } \\
\left(g k g^{-1}\right)\end{array}$ & $\begin{array}{c}\text { Fat } \\
\left(g k g^{-1}\right)\end{array}$ & $\begin{array}{c}\text { Protein } \\
\left(g k g^{-1}\right)\end{array}$ & $\begin{array}{c}\text { Ash } \\
\left(g^{-1} g^{-1}\right)\end{array}$ \\
\hline Ankra & 19.2 & 2.7 & 3.5 & 3.2 \\
91934 & 16.4 & 2.5 & 1.8 & 1.4 \\
ISU-W & 19.8 & 1.8 & 4.2 & 3.0 \\
$30001-W$ & 15.3 & 1.9 & 4.0 & 3.6 \\
30474 & 18.8 & 2.2 & 3.7 & 2.9 \\
60142 & 18.4 & 2.4 & 2.8 & 2.4 \\
LSD at 5\% & 1.03 & 0.8 & 1.0 & 0.4 \\
LSD at $1 \%$ & 1.37 & 1.1 & 1.3 & 0.6 \\
CV \% & 2.83 & 18.6 & 14.9 & 9.63 \\
\hline
\end{tabular}

TABLE 3

Proximate Composition of 6-month-old Cassava Root (Set B)

\begin{tabular}{lcccc}
\hline Variety & $\begin{array}{c}\text { Starch } \\
\left(g k g^{-1}\right)\end{array}$ & $\begin{array}{c}\text { Amylose } \\
(\%)\end{array}$ & $\begin{array}{c}\text { Ash } \\
\left(\mathrm{gkg}^{-1}\right)\end{array}$ & $\begin{array}{c}\text { Fibre } \\
\left(\mathrm{gkg}^{-1}\right)\end{array}$ \\
\hline Ankra & 684 & 20.9 & 12.2 & 42.9 \\
Akosua-Tuntum & 662 & 22.6 & 16.5 & 39.3 \\
60142 & 680 & 18.6 & 16.9 & 40.6 \\
ISU-W & 662 & 22.0 & 13.6 & 45.6 \\
Atra & 665 & 20.8 & 21.1 & 61.2 \\
518-DB & 677 & 21.8 & 13.5 & 54.5 \\
30001-W & 668 & 20.9 & 16.7 & 51.5 \\
ISU-DB & 668 & 20.3 & 17.7 & 55.6 \\
1425-DB & 660 & 20.1 & 15.8 & 55.9 \\
LSD at 5\% & 9.49 & 1.53 & 0.8 & 5.9 \\
LSD at 1\% & 12.7 & 2.04 & 1.1 & 7.9 \\
CV\% & 0.70 & 3.63 & 2.61 & 6.04 \\
\hline
\end{tabular}

Tables 2 and 3 give the proximate composition of the root and starch of the varieties. There were no statistically significant differences in starch content between the varieties harvested at 13 months, but statistically significant differences existed between varieties harvested at 6 months. This would suggest that some of the varieties had not attained their maximum starch content at six months. Ketibu \& Oyenuga (1972) also reported that peak starch content in cassava is reached at 8 months while Obigbesan \& Agboola (1973) reported that maximum starch content is not attained until 15 months. The amylose content of the starch, however, differed among the varieties, especially those harvested at 13 months. The apparently higher levels of amylose in the 6 month old material was not statistically tested.

The varieties in both maturity groups differed in the ash content of the root, but the average amount of ash in the root was not greatly influenced by the age of harvesting. Significant differences were established in the fibre and fat contents but not protein content of the root of the varieties in Set A. The components of the starch studied were fat, protein and ash for varieties in Set A. These represented very small proportions of the starches, 
and yet statistically significant differences were established between the varieties.

Proximate composition of root and cooking quality

The product-moment correlation coefficients between the cooking quality parameters and proximate composition are shown in Table 4. Many of

TABLE 4

Correlation Between Cooking Quality and Proximate Set $A$

Composition

Mealiness Elasticity Smoothness

\begin{tabular}{|c|c|c|c|}
\hline Ash content of starch & $0.80 *$ & 0.85 & 0.68 \\
\hline Ash content of root & $0.38^{n s}$ & 0.55 & 0.30 \\
\hline at content of starch & $-0.06 \mathrm{~ns}$ & -0.36 & -0.18 \\
\hline at content & $0.30 \mathrm{~ns}$ & -0.43 & -0.14 \\
\hline $\begin{array}{l}\text { rotein content of } \\
\text { tarch }\end{array}$ & $0.64^{n \mathrm{~s}}$ & $0.83^{*}$ & $0.68^{n s}$ \\
\hline Protein content of root & $0.81 *$ & $.35^{\text {ns }}$ & $0.71^{n s}$ \\
\hline Starch content of root & $0.64 \mathrm{~ns}$ & 0.33 & $0.36 \mathrm{~ns}$ \\
\hline & $0.22 \mathrm{ws}$ & 0.45 & 0.51 \\
\hline onter & $-0.45^{n \times}$ & 0.17 & -0.49 \\
\hline
\end{tabular}

Set B

\begin{tabular}{lrrr}
\hline Starch content & $0.61^{\mathrm{ns}}$ & $-0.10^{\mathrm{ns}}$ & $0.30^{\mathrm{ns}}$ \\
Amylose content & $0.09^{n \mathrm{~s}}$ & $0.58^{\mathrm{ns}}$ & $0.33^{\mathrm{ns}}$ \\
Ash content of root & $-0.12^{\mathrm{ns}}$ & $-0.09^{\mathrm{ns}}$ & $0.03^{\mathrm{ns}}$
\end{tabular}

$\mathrm{ns}=$ Not significant

$*=5$ per cent level of significance.

the correlation coefficients were not statistically significant, even though some of them were relatively high. This situation may be due to the small number of varieties used in the experiments rather than the complete absence of any relationship. With error degrees of freedom of 4 and 7 in the correlation analysis for Sets A and B respectively, the value of the correlation coefficient $(r)$ must be equal to or greater than 0.811 and 0.666 respectively before statistical significance could be established (Steel\& Torrie, 1960). The correlations are, there- fore, discussed in terms of their relative values instead of their statistical significance.

In both Sets A and B, the correlation between starch content and mealiness were relatively higher than those between starch content and elasticity or smoothness of the pounded paste. On the other hand, the correlation between amylose content and smoothness or elasticity was relatively higher than that between amylose content and mealiness. Olorunda, Awoth \& Numfor (1981) reported that mealiness was related to amylose content. But their finding and that in the present study are in contrast to Asaoka, Blanshard \& Rickard(1991) who did not find any relationship between the differences in eating quality and amylose content. The ash content of the starch was highly and significantly correlated to mealiness and elasticity and the correlation to smoothness, though not statistically significant, was high $(r=0.68)$.

The correlation coefficients between the cooking quality parameters and the protein content of the root and starch were relatively high and statistically significant in some cases. The fat content of the root and starch had no relationship with any of the cooking quality parameters. The correlation between fibre content and mealiness and smoothness were relatively high and negative, implying that varieties with very high fibre contents produce roots with unacceptable cooking qualities.

It may be concluded then, that even though differences exist in the proximate composition of cassava varieties, none of the components studied sufficiently explains all the observed differences in cooking quality. In spite of the lack of statistical significance in some cases, the magnitude of the correlation coefficients were high enough, in certain cases, to suggest the following:

1. Mealiness of the cooked root depends largely on the total starch content of the root, while the elasticity and smoothness of the pounded paste depends largely on the amylose content of the starch.

2. Varieties with high fibre contents may produce roots with unacceptable cooking qualities.

3. Of the minor components of cassava root and 
starch, the ash and protein contents were the only ones which were related to cooking quality, but the relationships were not very conclusive and calls for more investigation, so that we can better understand how chemical fertilization of cassava is likely to affect its cooking quality.

Hot paste viscosity

The results of the hot-paste viscosity studies
(1985). The lowest temperature at which pasting occurred was $66.5^{\circ} \mathrm{C}$ and the highest was $75^{\circ} \mathrm{C}$. In Set $\mathrm{A}$, the pasting temperature of the starch was higher than that of the flour. The gelatinization range was estimated as 4 he difference between the temperature of peak viscosity and the pasting temperature, shown as $\mathrm{T}$ in Tables 5 and 6 . Thure was a lot of variation in this parameter between the varieties, except in the flour of Set $B$, where $T$

TABLE 5

Viscosity of Starch and Flour Durmg Gelatmization (Set A)

\begin{tabular}{|c|c|c|c|c|c|c|c|c|}
\hline \multirow[b]{2}{*}{ ies } & \multicolumn{7}{|c|}{ Brabender viscosity units (BU) } & \multirow[b]{2}{*}{$\begin{array}{l}\text { Visc. after } \\
50^{\circ} \mathrm{C} \text { hold }\end{array}$} \\
\hline & $\begin{array}{l}\text { Pasting Tempera- } \\
\text { tempera-ture of peak } \\
\text { ture }{ }^{\circ} \mathrm{C} \text { viscosity }{ }^{\circ} \mathrm{C}\end{array}$ & $\Delta T$ & $\begin{array}{l}\text { Peak } \\
\text { visc. }\end{array}$ & $\begin{array}{l}\text { Visc. at } \\
95^{\circ} \mathrm{C}\end{array}$ & $\begin{array}{c}\text { Visc. after } \\
\triangle P / 95 " C \text { hold } \triangle P 2\end{array}$ & $\begin{array}{l}\text { Visc. at } \\
50 \text { "C }\end{array}$ & $\triangle P 3$ & \\
\hline
\end{tabular}

Cassava starch $\left(70 g l^{-1}\right)$

$\begin{array}{lrrrrrrrrrrr}\text { Ankra } & 74 & 82 & 8 & 560 & 460 & 100 & 260 & 43 & 480 & 85 & 420 \\ 91934 & 74 & 77 & 3 & 500 & 380 & 120 & 145 & 62 & 280 & 95 & 240 \\ 60142 & 69 & 77 & 8 & 440 & 390 & 50 & 200 & 49 & 430 & 115 & 360 \\ 30474 & 71 & 85 & 14 & 340 & 290 & 50 & 140 & 52 & 280 & 100 & 260 \\ \text { ISU-W } & 75 & 83 & 8 & 300 & 260 & 40 & 160 & 39 & 260 & 63 & 230 \\ \text { 30001-W } & 68 & 83 & 15 & 400 & 360 & 40 & 240 & 33 & 420 & 75 & 360\end{array}$

Cassava flour $\left(70 \mathrm{gl}^{-1}\right)$

$\begin{array}{llllrrrrrrrr}\text { Ankra } & 68 & 76 & 8 & 490 & 320 & 170 & 150 & 53 & 280 & 87 & 250 \\ 91934 & 68 & 72.5 & 4.5 & 380 & 40 & 340 & 0 & 100 & 0 & - & 0 \\ 60142 & 69.5 & 74 & 4.5 & 300 & 210 & 90 & 80 & 62 & 140 & 75 & 130 \\ 30474 & 71 & 78.5 & 75 & 90 & 60 & 30 & 30 & 50 & 50 & 67 & 50 \\ \text { ISU-W } & 69.5 & 76.3 & 6.8 & 300 & 210 & 90 & 80 & 62 & 140 & 75 & 120 \\ 30001-W & 68 & 78.5 & 10.5 & 300 & 200 & 100 & 60 & 70 & 120 & 100 & 110\end{array}$

Cassava flour $\left(70 \mathrm{~g} t^{-1}\right)$

\begin{tabular}{llllrrrrrrrr} 
Ankra & 68 & 77 & 9 & 1100 & 780 & 320 & 300 & 62 & 600 & 100 & 600 \\
91934 & 67.3 & 71 & 3.7 & 880 & 70 & 810 & 10 & 86 & 20 & 100 & 20 \\
60142 & 69.5 & 75.5 & 6 & 980 & 500 & 480 & 120 & 76 & 320 & 167 & 320 \\
30474 & 69.5 & 74 & 4.5 & 380 & 120 & 260 & 50 & 58 & 120 & 140 & 120 \\
ISU-W & 68 & 75.5 & 7.5 & 950 & 460 & 490 & 140 & 70 & 300 & 114 & 300 \\
$30001-W$ & 68 & 74 & 6 & 940 & 60 & 480 & 110 & 76 & 260 & 136 & 260 \\
\hline
\end{tabular}

$\Delta T=$ Temperature of peak viscosity - Pasting temperature $\Delta \mathrm{P} 2=100 \times \frac{\text { Viscosity at } 95^{\circ} \mathrm{C}-\text { Viscosity } 95^{\circ} \mathrm{C} \text { hold }}{\text { Viscosity at } 95^{\circ} \mathrm{C}}$

using the Brabender Amylograph are presented in Tables 5 and 6, and discussed below.

Pasting temperature. There were differences among the varieties in the pasting temperature, which agrees with an observation by Moorthy
$\Delta \mathrm{Pl}=$ Peak viscosity - viscosity at $95^{\circ} \mathrm{C}$

$\Delta P 3=\frac{\text { Visc. at } 50^{\circ} \mathrm{C}-\text { Visc. after } 95^{\circ} \mathrm{C} \text { hold }}{\text { Visc. after } 95^{\circ} \mathrm{C} \text { Hold }} \times 100$

values were more uniform. Rosenthal et al. (1974) and Synder (1984) also established varietal differences in the gelatinization range.

Peak viscosity. An examination of varieties which appeared in both Sets A and B shows that, 
TABLE 6

Viscosity Changes of Starch and Flour During Gelatinization (Set B)

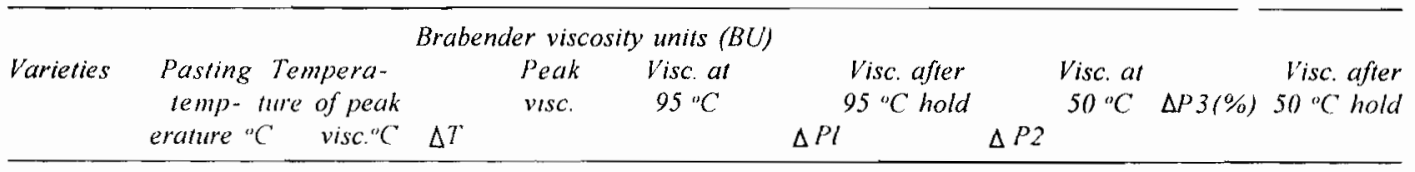

Cassava starch $\left(70 g^{-1}\right)$

$\begin{array}{llllllrlllll}\text { Ankra } & 71 & 80 & 9 & 420 & 400 & 20 & 220 & 45 & 400 & 82 & 360 \\ \text { Akosua } & & & & & & & & & & & \\ \text { Tuntum (AK-T) } & 72.5 & 80 & 7.5 & 360 & 290 & 70 & 150 & 48 & 280 & 87 & 270 \\ \text { Atra } & 69.5 & 74.5 & 5 & 540 & 360 & 180 & 200 & 44 & 380 & 90 & 340 \\ \text { 518-DB } & 68 & 80 & 12 & 310 & 290 & 20 & 180 & 38 & 320 & 78 & 290 \\ \text { I425-DB } & 66.5 & 77 & 10.5 & 460 & 320 & 80 & 180 & 44 & 320 & 78 & 290 \\ \text { ISU-W } & 69.5 & 72.5 & 3.0 & 510 & 390 & 120 & 250 & 36 & 420 & 68 & 360 \\ \text { ISU-DB } & 66.5 & 72.5 & 6.0 & 460 & 390 & 70 & 300 & 23 & 500 & 67 & 420 \\ \text { 30001-W } & 71 & 80 & 9.0 & 380 & 320 & 60 & 220 & 31 & 380 & 73 & 340 \\ 60142 & 69.5 & 75.5 & 6.0 & 400 & 220 & 80 & 120 & 45 & 240 & 100 & 240\end{array}$

Cassava flour (70gl')

\begin{tabular}{lllllrlrlrrr} 
Ankra & 69.5 & 75.5 & 6 & 260 & 140 & 120 & 70 & 50 & 120 & 71 & 120 \\
Akosua & & & & & & & & & & & \\
Tuntum (AK-T) & 66.5 & 72 & 4.5 & 390 & 220 & 170 & 80 & 64 & 140 & 75 & 120 \\
Atra & 69.5 & 74 & 4.5 & 280 & 150 & 130 & 60 & 60 & 120 & 100 & 100 \\
$518-\mathrm{DB}$ & 69.5 & 74 & 4.5 & 200 & 80 & 120 & 40 & 50 & 60 & 50 & 60 \\
1425-DB & 69.5 & 74 & 4.5 & 440 & 270 & 170 & 100 & 63 & 180 & 80 & 160 \\
ISU-W & 68.8 & 73.3 & 4.5 & 400 & 220 & 180 & 80 & 64 & 150 & 88 & 140 \\
ISU-DB & 66.5 & 71 & 4.5 & 390 & 210 & 180 & 60 & 71 & 100 & 67 & 100 \\
$30001-$ W & 69.5 & 74 & 4.5 & 260 & 100 & 160 & 60 & 40 & 100 & 67 & 100 \\
60142 & 69.5 & 74.8 & 5.3 & 250 & 60 & 190 & 30 & 50 & 50 & 67 & 50 \\
\hline
\end{tabular}

$\Delta T=$ Temperature of peak viscosity - Pasting temperature. $\Delta \mathrm{P} 2=100 \times$ Viscosity at $95^{\circ} \mathrm{C}-$ Viscosity $95^{\circ} \mathrm{C}$ hold

$\Delta \mathrm{Pl}=$ Peak Viscosity - Viscosity at $95^{\circ} \mathrm{C}$

$\Delta \mathrm{P} 3=\frac{\text { Visc. at } 50^{\circ} \mathrm{C}-\text { Visc. after } 95^{\circ} \mathrm{C} \text { hold }}{\text { Visc. after } 95^{\circ} \mathrm{C} \text { hold }} \times 100$

with the exception of ISU-W, the peak viscosity of the 13-month old materials was higher than the 6month old materials, thus showing that age at harvest has an effect on the extent of swelling of the granules. There was a similar trend with the flour. The viscosity of the flour was generally lower than that of the starch at the same concentration, but the differences in some varieties were remarkably large. Moorthy, Richard \& Blanshard (1994) found a similar difference between the viscosity of the cassava starch and flour and attributed this to the higher fibre content of the flour.

Viscosity at $95^{\circ} \mathrm{C}$. According to Tipples (1982), the viscosity at $95^{\circ} \mathrm{C}$ in relation to theqpeak viscos-

ity reflects the fragility of the swollen granules. This change in viscosity is shown as $\Delta P 1$ in Tables 5 and 6 . The results again showed a great deal of variation between the varieties and $\mathrm{P} 1$ was larger in the flour than in the starch. The change in viscosity, $\mathrm{P} 1$, in the flour of the varieties 91934 and 30474 was outstanding. In 91934, there was a drop from 380 to $40 \mathrm{BU}$, but 30474 had a peak viscosity of $90 \mathrm{BU}$ and dropped by only 30 units. A similar observation was made with the $100 \mathrm{~g} l^{-1}$ flour samples. Among the varieties studied, therefore, the granules of 91934 swelled most readily while 30474 granules had the least ability to swell. The starch of the 6-month old varieties also showed 
much variation in $\mathrm{Pl}$ and these differed from those in Set $\mathrm{A}$.

Viscosity after the $95^{\circ} \mathrm{C}$ hold. According to Tipples (1982), the viscosity after cooking at $95^{\circ} \mathrm{C}$ shows the stability or breakdown of the paste during conking, especially when compared to the peak viscosity or the viscosity at the beginning of the hold. P2 in Tables 5 and 6 gives the percentage drop in viscosity at the end of the hold as compared to the viscosity at the beginning of the hold. This shows that in both Sets A and B, the proportional breakdown of the paste in the flour was higher than in the starch. Again, the two varieties 91934 and 30474 showed the opposite extremes. After cooking for one hour at $95^{\circ} \mathrm{C}$, the starch of 91934 had the greatest proportional break down, and the $70 \mathrm{~g} l^{-1}$ flour sample was no longer a viscous paste while the $100 \mathrm{~g} l^{-1}$ flour sample which had a peak viscosity of 880 BU had now dropped to $10 \mathrm{BU}$. This again shows the high degree of fragility of the swollen granules of 91934 . The 70 and $100 \mathrm{gl}^{-3}$ flour samples of 30474 underwent the least change in viscosity which may be due to the fact that there was very little swelling of its granules.

$V i s c o s i t y$ at $50{ }^{\circ} \mathrm{C}$. The extent of the increase in viscosity on cooling to $50^{\circ} \mathrm{C}$ reflects the retrogradation tendency of the starch product (Tipples, 1982). P3 in Tables 5 and 6 represents the percentage increase in viscosity when the paste is cooled from $95^{\circ} \mathrm{C}$ to $50^{\circ} \mathrm{C}$. There was a great deal of variation among the varieties in both Sets $A$ and B. For the varieties in Set A, retrogradation was highest in the $100 \mathrm{gl}^{-1}$ flour sample, but retrogradation of the pure starch at $70 \mathrm{~g} t^{-1}$ was higher than that of the flour at the same concentration. The variety 60142 showed the greatest retrogradation tendency among the starches of both maturity groups.

According to Tipples (1982), the viscosity

TABLE 7

Correlation Between Cooking Quality and Pasting Cycle

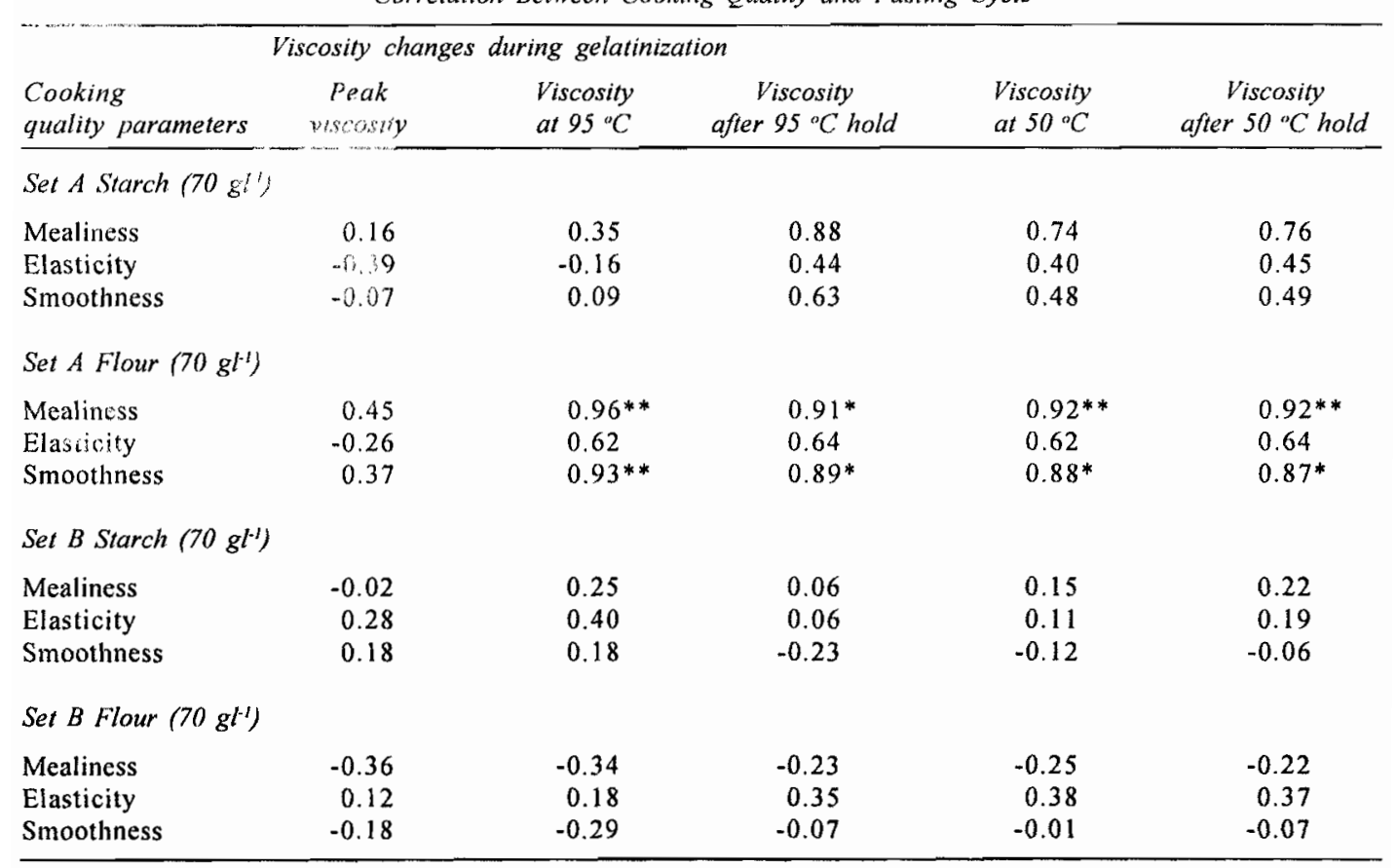

\footnotetext{
* 5 per cent of significance

** 1 per cent of significance
} 
changes during the hold at $50^{\circ} \mathrm{C}$ indicate the stability of the cooked paste as it might be used. There were only slight changes in viscosity during this period.

\section{Relationship of viscosity changes to cooking} quality

From the product-moment correlation coefficients between the cooking quality rankings and the various points on the amylograph (Table 7), it is difficult to predict the cooking quality from any specific point on the amylograph. However, it was possible to make the following distinctions between the varieties from the amylographs. A good cooking variety might be expected to have granules which swell to a great extent (peak viscosity); these swollen granules should not break down easily (viscosity at $95^{\circ} \mathrm{C}$ and after $95^{\circ} \mathrm{C} \mathrm{hold}$ ); and the paste should not harden to a large extent when cooled (retrogradation tendency). A deficiency at any of these points will not produce a good cooking variety. Once again, taking the variety 91934 as an example, we can see that it had one of the highest peak viscosities which was reached within the shortest temperature range-gelatinization range. However, it had the most fragile swollen granules especially in the flour, and at the end of the $95^{\circ} \mathrm{C}$ hold, it was no longer a viscous paste. It is not a good cooking variety. The variety 30474 illustrated the opposite extreme. The $70 \mathrm{~g} l^{-1}$ flour sample had the lowest peak viscosity while the starch sample also showed one of the lowest values. The gelatinization range was relatively high. This suggests that the granules of 30474 do not swell easily and that may be due to strong bonding forces between the granules. Compared to the peak viscosity value, there was a 50 per cent drop in viscosity at the $95^{\circ} \mathrm{C}$ hold and it also showed a relatively high retrogradation tendency. The poor cooking quality of 30474 may, therefore be largely due to the strong forces between the granules. Ankra which was the best cooking variety had the highest peak viscosity, and at $95^{\circ} \mathrm{C}$ it still produced the most viscous paste and had a retrogradation tendency not too different from the other varieties. The other
TABLE 8

Swelling Power and Solubility at $85^{\circ} \mathrm{C}$

Variety Swelling power Solubility (per cent)

Set $A$

$\begin{array}{lrr}\text { Ankra } & 33.60 & 22.46 \\ 91934 & 47.79 & 31.12 \\ \text { ISU-W } & 25.96 & 19.31 \\ 30001-W & 22.48 & 21.12 \\ 30474 & 21.71 & 19.96 \\ 60142 & 27.11 & 17.96 \\ & & \\ \text { LSD }(5 \%) & 9.93 & 1.08 \\ \text { LSD (1\%) } & 13.36 & 1.45\end{array}$

Set $B$

\begin{tabular}{lrr} 
Ankra & 24.63 & 16.33 \\
Ak-T & 34.96 & 25.23 \\
Atra & 32.13 & 20.84 \\
60142 & 27.21 & 22.57 \\
ISU-W & 38.44 & 20.49 \\
$518-\mathrm{DB}$ & 33.31 & 25.58 \\
$30001-\mathrm{W}$ & 31.94 & 27.02 \\
ISU-DB & 35.94 & 19.39 \\
1425-DB & 34.51 & 25.15 \\
LSD (5\%) & 1.46 & 0.75 \\
LSD (1\%) & 1.96 & 1.00 \\
\hline
\end{tabular}

varieties were intermediate.

\section{Swelling power and solubility}

The results of the swelling power (SWP) and solubility determined at $85^{\circ} \mathrm{C}$ are presented in Table 8. Statistically significant differences for both parameters were established between the varieties. Moorthy \& Ramanujam (1986) also found differences in SWP and solubility between cassava cultivars in India. The swelling power of an aqueous suspension of starch is an indication of the strength of the hydrogen bonding between the granules. The results, therefore, show that the bonding forces between the granules vary between the varieties and confirm the observations made in the amylograph studies.

The correlation coefficients between SWP and solubility and the cooking quality parameters are presented in Table 9. The only coefficients that were statistically significant were those between 
TABLE 9

Correlation between Cooking Quality, Swelling Power and Solubility

\begin{tabular}{lcc}
\hline Variety & Swelling porer & Solubility \\
\hline Set $A$ & & \\
Mealiness & 0.43 & -0.54 \\
Elasticity & $0.87^{*}$ & $-0.94^{* *}$ \\
Smoothness & 0.56 & -0.63 \\
Set B & & \\
Mealiness & 0.64 & \\
Elasticity & 0.12 & -0.64 \\
Smootlnness & 0.47 & -0.17 \\
\hline
\end{tabular}

* 5 per cent signilicance

** 1 per cent significance

SWP and solubility and elasticity in Set A, but there were no significant correlations in Set B. In all cases, the correlations were negative, indicating that the higher the SWP or the weaker the binding forces between the granules, the less desirable the cooked or pounded product. There were exceptions such as 30474 which had very strong binding forces but had poor cooking quality.

The differences in the strength of the bonding forces between the granules of the different varieties became more apparent when the SWP and solubility of the three varieties Ankra, 91934 and 30474 were studied over the temperature range of $60-95{ }^{\circ} \mathrm{C}$. The three were chosen because they showed very distinct differences in their amylograph behaviour and also differed in their cooking qualities. The results are presented graphically in Fig. 1 and 2.

The SWP and solubility curves show that the starches of the three varieties differed in the rate of swelling of their granules. The variety 91934 showed a very rapid rate of swelling which suggests that its granules have relatively weak bonding forces. This would explain why in the amylograph studies, 91934 lost its viscosity in the flour after stirring at $95^{\circ} \mathrm{C}$ for one hour. The variety 30474 had the slowest rate of swelling of the three varieties, and this would agree with its amylograph behaviour

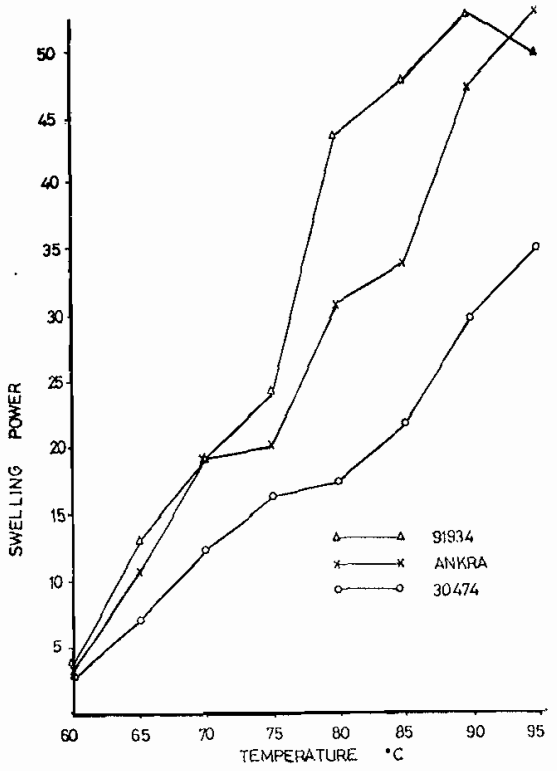

Fig.1. The effect of temperature on the swelling power of three cassava varieties

I

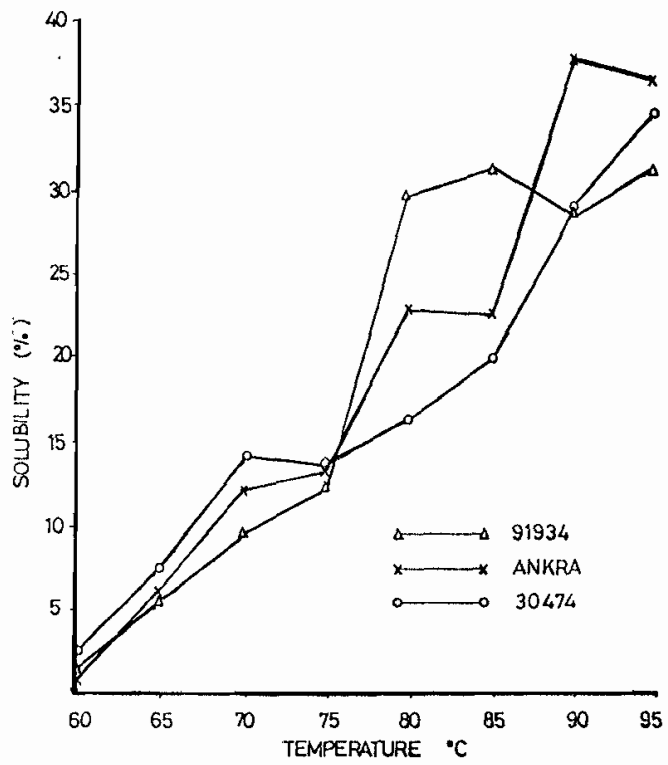

Fig. 2. The effect of temperature on the solubility of three cassava varieties 
which showed very low hot-paste viscosity values. The rate of swelling of Ankra was intermediate between the other two varieties.

The two varieties 91934 and 30474 had the poorest cooking quality in terms of mealiness and smoothness of the pounded paste. Ankra gave the best results. The three varieties, therefore, show that for good cooking quality, a gradual swelling as occurred in Ankra is desirable. Too rapid swelling indicating very weak bonding forces as occurred in 91934, results in poor cooking quality. Similarly, too strong bonding forces as occurred in 30474 , results in poor cooking quality.

It may be concluded that the chemical and rheological analyses undertaken in this study help to explain the differences in cooking quality between cassava varieties but none seems to provide a simple method of objective assessment which could be used by the plant breeder as selection criterion.

\section{Acknowledgement}

This research was undertaken as part of the Internationai Atomic Energy Agency (IAEA) Research Contract No.GHA/5416. A six-month fellowship awarded to the senior author by the IAEA enabled him to travel to Rome, Italy to undertake the research. The assistance is gratefully acknowledged.

\section{REFERENCES}

AOAC (1984) Official methods of analysis, 14th ed. Washington D.C.: Association of Official Analytical Chemists.

AOAC (1990) Official methods of analysis, 20th ed. Washington D.C.: Association of Official Analytical Chemists.

Asaoka, M., Blanshard, J. M. V. \& Rickard, J. E. (1991) Seasonal effects on the physico-chemical properties of starch from four cultivars of cassava. Starch/Starke 43, 155-159.

Bettelheim, F. A. \& Sterling, C. (1955) Factors associated with potato texture. I. Specific gravity and starch content. Fd Res. 20, 71.

Brabender Ohg Duisburg (1989) Brabender amylograph instruction manual No. 1732E.

Howard, H.W. (1974) Factors influencing the quality of ware potatoes. I. The genotype. Potato Res. 17,490-
511.

Ketiku, A.O. \& Oyenuga, V. A. (1972) Changes in the carbohydrate constituents of cassava root-tuber during growth. J. Sci. Fd Agric. 23, 1451-1456.

Linehan, D. J. \& Hughes, J. C. (1969) Texture of cooked potato. I. Introduction. J. Sci. Fd Agric. 20, 110-112.

Mazurs, E. G., Schoch, T. J. \& Kite, E. E. (1957) Graphical analysis of the Brabender viscosity curves of various starches. Cereal Chem. 43, 141.

McCready, R. M. \& Hassid, W. Z. (1943) The separation and quantitative estimation of amylose and amylopectin in potato starch. J. Am. Chem. Soc. 65, 1154.

Moorthy, S. N. (1985) Cassava starch and its modifications. Techn. Bull. Series 4. Trivandrum, India: Central Tuber Crop Research Institute.

Moorthy, S. N. \& Ramanujam, T. (1986) Variation in properties of starch varieties in relation to age of the crop. Starch/Starke 38 (2), 58-61.

Moorthy, S. N., Rickard, J. \& Blanshard, J. M. V. (1994) Influence of the gelatinization characteristics of cassava starch and flour on the textural properties of some products. Proceedings of the International Meeting on Cassava Flour and Starch. CIAT. Cali, Colombia. 11-15 Jan 94.

Obigbesan, G. O. \& Agboola, A. A. (1973) 3rd Int. Symp. Trop. Root Crops. IITA, Ibadan, Nigeria.

Olorunda, A. O., Awoth,O.C.\& Numfor, F.A.(1981) Predicting quality of cassava products with the aid of chemical and rheological properties. J.Fd. Technol. $16,447-450$.

Rasper, V. (1969) Investigations on starches from major starch crops grown in Ghana. I. Hot paste viscosity and gel-forming power. J. Sci. Fd. Agric. 20, 165.

Rasper, V. (1982) Theoretical aspects of amylography. Ch. 1, Brabender Viscoamylograph Handbook.

Rickard, J. E. \& Behn, K. R. (1987) Evaluation of acid and enzyme hydrolytic methods for the determination of cassava starch. J. Sci. Fd Agric. 41, 37.

Rosenthal, F. R. T., Nakamura, T., Espindola, A. M. C. \& Jochimek, M. R. (1974) Structure of starch granules. Starch/Starke 26 (2), 50-55.

Safo-Kantanka, O. \& Owusu-Nipa, J. (1992) Cassava varietal screening for cooking quality: Relationship between dry matter, starch content, mealiness and certain microscopic observations of the raw and cooked tuber. J. Sci. Fd Agric. 60 (1), 99.

Schoch, T. J. (1964) Swelling power and solubility of granular starches. In Methods in carbohydrate chem- 
istry (ed. R.L. Whistler), Vol. IV. Starch. New York: Academic Press.

Steel, R. G. D. \& Torrie, J. H. (1960) Principles and procedures of statistics, Ch. 10. New York: McGrawHill Book Co.

Synder, E. M. (1984) Industrial microscopy of starches.
In Starch chemistry and technology (ed. R.L. Whistler, J.N. Bemiller and F.F. Paschall), p. d469. New York: Academic Press.

Tipples, K. H. (1982) Uses and application, Ch. III. Brabender Viscoamylograph Handbook. 